\title{
ROLA INICJATYWY PASA I SZLAKU W REFORMIE SYSTEMU GLOBALNEGO ZARZAQDZANIA
}

Inicjatywa Pasa i Szlaku budzi duże emocje na arenie międzynarodowej od czasu jej ogłoszenia w 2013 r. Skala tego przedsięwzięcia i cele, jakie przyświecają jego realizacji, świadczą bowiem o tym, że może mieć ono znaczący wpływ na zmianę układu sił w dzisiejszych stosunkach międzynarodowych. Niniejszy artykuł stanowi próbę odpowiedzi na pytanie, czy Nowy Jedwabny Szlak jest sposobem Chin na reformę systemu globalnego zarządzania? Jeśli tak, to w jakim stopniu? Aby to rozstrzygnąć, zastosowano metodę opisu rzeczywistości gospodarczej i wyciagnięto wnioski co do przyszłości global governance. Przeprowadzona analiza potwierdziła tezę, że patrząc na obecny układ sił w gospodarce globalnej i rosnącą rolę geopolityczną Chin, wydają się one dziś jedynym podmiotem, który mógłby zmienić kształt systemu global governance. Jest to jednak proces długofalowy.

\section{Global governance - ujęcie definicyjne}

W ciagu ostatnich 20-30 lat pojęcie ,globalne zarządzanie” (global governance) zostało przez badaczy międzynarodowych stosunków gospodarczych znacznie spopularyzowane. Dziś używa się go niemal równie często, co pojęcia „globalizacja” i czasem nawet przypisuje się tym zjawiskom podobne cechy. Choć to zrozumiałe i nie da się tego uniknąć, gdyż procesy globalizacyjne w zasadzie wymusiły rozwój koncepcji globalnego zarządzania, to mylne jest utożsamianie tych pojęć. Wraz ze wzrostem rozmiarów wymiany handlowej oraz przepływów osób, kapitału i technologii zaczęły zanikać bariery ekonomiczne między krajami, a więzi gospodarcze zaczęły się zacieśniać. Świat stopniowo przekształcił się w jeden globalny rynek i aby wszystkie podmioty mogły na nim zgodnie koegzystować, konieczne stało się stworzenie systemu pozwalającego pogodzić ich interesy oraz wspomóc ich w rozwiązywaniu problemów i sporów na arenie międzynarodowej. Aktualnie nie ma szans na utworzenie rządu światowego, który w sposób demokratyczny podejmowałby decyzje wiążące wszystkie podmioty funkcjonujące w gospodarce

ORCID: 0000-0001-5738-1033, DOI: 10.4467/23538724GS.20.024.12142 
światowej (państwa, przedsiębiorstwa międzynarodowe, instytucje, organizacje międzynarodowe, ugrupowania integracyjne). Obecny kształt systemu światowego zarządzania pozostawia autonomię rządom krajowym - żadna władza na poziomie krajowym nie zdecyduje się bowiem $\mathrm{w}$ dzisiejszych czasach na całkowite oddanie swojej suwerenności i kontroli nad procesami gospodarczymi, a także związanymi z nimi procesami społecznymi i politycznymi na rzecz władzy centralnej na poziomie światowym. Jednocześnie brak podmiotu, który odpowiadałby za koordynację działań podejmowanych przez różnych uczestników stosunków międzynarodowych, powoduje, że są one często chaotyczne, przypadkowe i zwykle podyktowane realizacją własnych interesów. Bez względu na rodzaj podmioty kształtujące stosunki międzynarodowe są w stanie współpracować jedynie w sytuacji, gdy ta kooperacja będzie im się opłacać. Dlatego tak bardzo wskazane jest zarządzanie tym procesem, szczególnie w celu ochrony interesów tych, którzy mają mniejszą siłę przetargowa.

Problem z określeniem granic pojęcia global governance pojawia się już na poziomie definicyjnym. Sam James N. Rosenau, uznawany za jednego z ojców idei globalnego zarządzania, przedstawia kilka podejść do tego zjawiska, raz ujmując je dość ogólnie jako: „porządek, który nie posiada centralnej władzy, ale ma zdolność do wprowadzania decyzji na skalę globalną"1, innym zaś razem odwołując się do struktury podmiotowej: „systemy rządów na wszystkich poziomach ludzkiej aktywności - od rodziny po organizację międzynarodowa - w których realizacja celów poprzez sprawowanie kontroli ma ponadnarodowe konsekwencje"2. Nieco szersza i bardziej rozbudowaną definicję tego terminu zaproponowała w $1995 \mathrm{r}$. w raporcie Our Global Neighbourbood Komisja ds. Globalnego Zarządzania: ,global governance to zbiór sposobów regulowania wspólnych spraw przez publiczne i prywatne instytucje. Powinien on doprowadzić do pogodzenia sprzecznych i zróżnicowanych interesów oraz zainicjować wspólne działania. W grę wchodzą nie tylko formalne instytucje i ośrodki władzy, ale także nieformalne regulacje, na których wdrożenie ludzie $\mathrm{i}$ instytucje się zgodzili oraz w których widzą możliwość realizacji swoich interesów”. Podobnie Ian Clark nazywa globalne zarządzanie „luźnym systemem globalnej regulacji zachowań aktorów polityki międzynarodowej, o charakterze instytucjonalnym lub normatywnym, złożony z różnego rodzaju elementów: organizacji międzynarodowych i prawa międzynarodowego, organizacji ponadnaro-

1 J.N. Rosenau, E.O. Czempiel, Governance Without Government: Order and Change in World Politics, Cambridge - New York 1992, s. 7.

2 J.N. Rosenau, Governance in the Twenty-first Century, „Global Governance” 1995, no. 1, s. $13-43$.

3 Commission on Global Governance, Our Global neighborhood: the report of the Commission on Global Governance, Oxford - New York 1995, https://www.gdrc.org/u-gov/global-neighbourhood/chap1.htm (dostęp: 1.03.2020). 
dowych i ram działania, elementów globalnej społeczności obywatelskiej, ogólnie przyjętych norm postępowania".

Wśród definicji globalnego zarządzania wyróżnia się także ta zaproponowana przez T.J. Bierstekera: ,globalne zarządzanie jest ujętym intersubiektywnie, ukierunkowanym na cel porządkiem na poziomie globalnym, który determinuje, ogranicza i kształtuje oczekiwania aktorów/uczestników w omawianym obszarze. To system posiadających poparcie reguł (o różnym stopniu instytucjonalizacji) działających i mających zastosowanie na poziomie globalnym. By taki system reguł mógł działać na globalnym poziomie, nie wymaga się ich powszechnego praktykowania czy uznawania za posiadające legitymizację. Wymagane jest tylko, by były one szeroko rozpowszechniane i praktykowane w skali globalnej (na wielu kontynentach) przez istotnych graczy"5. Autor w przytoczonej definicji zwrócił uwagę na kilka kluczowych elementów, takich jak: działania ukierunkowane na cel globalny, poparcie systemem zasad (reguł) oraz globalną akceptację poprzez ich praktykowanie.

Anthony McGrew odnosi się natomiast bezpośrednio do celu tejże idei: ,global governance polega na mniej lub bardziej skutecznym zarządzaniu problemami wspólnymi dla całej ludzkości, podkreślaniu ich znaczenia, wprowadzaniu norm i podejmowaniu bezpośredniej interwencji”" W polskiej literaturze przedmiotu często przytaczana jest definicja zaproponowana przez Marka Pietrasia. Odwołuje się on do źródeł pochodzenia tej koncepcji i jej związku z procesem globalizacji: ,globalne zarządzanie pomyślane jest jako alternatywa dla właściwych procesom globalizacji mechanizmów rynkowych, odwołujących się do idei autoregulacji i jednoczesnej deregulacji funkcji współczesnych państw. Jest to także wyraz dążenia do zachowania nadrzędności płaszczyzny politycznej nad systematycznie zyskującą w warunkach procesów globalizacji płaszczyzną gospodarczą stosunków międzynarodowych"7.

$\mathrm{Na}$ podstawie analizy licznych definicji global governance można wyróżnić kilka cech charakterystycznych dla tej idei:

- duża liczba podmiotów wpływających na kształtowanie zasad i reguł postępowania oraz podejmowania decyzji na poziomie globalnym (rządy, społeczeństwo, korporacje transnarodowe, organizacje międzynarodowe, ugrupowania integracyjne itd.),

- jej zasadniczym celem jest poszukiwanie porozumienia na arenie międzynarodowej poprzez współpracę i podejmowanie wspólnych decyzji na różnych poziomach zarządzania,

4 I. Clark, Globalizacja i ład pozimnowojenny [w:] Globalizacja polityki swiatowej. Wprowadzenie do stosunków miedsynarodowych, red. J. Baylis, S. Smith, tłum. Ł. Kamieński, M. Filary, Kraków 2008, s. 903.

5 T.J. Biersteker, Global governance [w:] Routledge Companion to Security, eds. M. Dunn Cavelty, V. Mauer, New York - London 2009, s. 2-5.

6 A. McGrew, Globalizacja i polityka globalna [w:] Globalizacja polityki światowej..., s. 32.

7 M. Pietraś, Hybrydowośćpóźñowestfalskiego tadu międrynarodowego [w:] Późnowestfalski ład międzynarodowy, red. M. Pietraś, K. Marzęda, Lublin 2008, s. 72. 
- powinna być oparta na demokratycznej „miękkiej” władzy,

- ma godzić interesy wszystkich jej uczestników i odzwierciedlać wspólne interesy, motywujące podmioty do kolektywnego działania,

- zakłada odejście od hierarchicznego modelu podejmowania decyzji i sprawowania władzy.

Wspomniane poziomy globalnego zarządzania obejmują:

- poziom międzyrządowy, na którym negocjuje się warunki współpracy, rozstrzyga spory i omawia procesy zachodzące w obrębie państw, a podmiotami decyzyjnymi są szefowie rządów oraz urzędnicy państwowi wysokiego szczebla,

- poziom transrządowy, na którym osoby pełniące funkcje niższych urzędników państwowych z różnych krajów współpracują w celu wypracowania założeń wspólnych polityk realizowanych przez państwa,

- poziom transnarodowy, na którym podmioty publiczne i prywatne koordynują działania nastawione na osiagnięcie wspólnych celów.

Podsumowując kwestie definicyjne, należy zwrócić uwagę na fakt, że w polskiej literaturze przedmiotu można się spotkać z różnym tłumaczeniem wyrażenia global governance. Poza sformułowaniem „globalne zarządzanie” autorzy stosują jeszcze m.in. takie określenia, jak: „globalne sterowanie”, „globalne rządzenie”, „światowe władztwo” czy „kierownictwo światowe”. W niniejszej publikacji zdecydowano się używać tłumaczenia „globalne zarządzanie”. Rządzenie raczej odnosi się do działań opartych na władzy formalnej, natomiast zarządzanie do działań opartych na wspólnych celach, stąd wybór tego określenia wydaje się bardziej trafny?.

\section{Global governance - ujęcie historyczne}

Jak wspomniano, upowszechnienie się koncepcji globalnego zarządzania było pochodną rozwoju międzynarodowej wymiany handlowej oraz utworzenia jednego globalnego rynku. Ekonomiści są zgodni co do faktu, że wraz z dynamicznym rozwojem procesu globalizacji pod koniec XX wieku nastapił także rozwój idei global governance, jednakże jej początków należy upatrywać znacznie wcześniej. Próby stworzenia międzynarodowego systemu pokojowej współpracy podejmowano bowiem wielokrotnie, najczęściej po konfliktach zbrojnych. Na przykład po wojnach napoleońskich podmiotem, który miał pełnić funkcję rządu światowego, było Święte Przymierze, zaś po I wojnie światowej koordynację działań mających na celu wspólne

8 M. Pollack, G. Shaffer, Transatlantic Governance in the Global Economy, Lanham 2001, s. 234.

9 M. Zachara, Global governance. Lad międzynarodowy po zakończeniu stulecia Ameryki, Kraków 2012, s. 21. 
zarządzanie globalne powierzono Lidze Narodów ${ }^{10}$. Po II wojnie światowej rolę instytucji odpowiedzialnej za pokojowe współdziałanie miała odgrywać Organizacja Narodów Zjednoczonych (ONZ), która w znaczącym stopniu przyczyniła się do budowy obecnego systemu global governance, jednakże nie pozostała do dziś jedynym podmiotem kształtującym zasady i reguły współpracy na arenie międzynarodowej. Stało się tak, ponieważ ONZ, mimo że odpowiada za koordynację wielu sfer międzynarodowej rzeczywistości, nie nadzoruje wszystkich, co potwierdza ograniczenie funkcjonalne tej organizacji i jednocześnie dowodzi, że stworzenie jednego podmiotu o charakterze „rządu światowego” jest praktycznie niemożliwe.

Potrzeba opracowania zasad funkcjonowania podmiotów w przestrzeni międzynarodowej na wielu polach wymusiła konieczność stworzenia innych organizacji $\mathrm{i}$ instytucji międzynarodowych, które dziś odgrywają istotną rolę w systemie global govenrance. Mowa tu np. o Międzynarodowym Funduszu Walutowym (IMF), Układzie Ogólnym ws. Taryf Celnych i Handlu oraz Światowej Organizacji Handlu (GATT/ WTO), Światowej Organizacji Pracy (ILO), Światowej Organizacji Zdrowia (WHO), Unii Europejskiej, Organizacji Paktu Północnoatlantyckiego (NATO) itd.

Do zacieśniania międzynarodowej współpracy gospodarczej, która rozwija się dynamicznie od lat 90. XX wieku, a co za tym idzie - do rozwoju systemu global governance przyczyniły się przemiany, jakie zaszły w tamtym czasie w Europie i Azji, począwszy od upadku komunizmu w Polsce, upadku Muru Berlińskiego, a także rozpadu Zwiazku Socjalistycznych Republik Radzieckich (ZSRR) i przede wszystkim dzięki zakończeniu zimnej wojny, podczas której świat był podzielony na dwa bloki. Ponadto ogromną rolę w obecnym kształcie stosunków międzynarodowych na świecie odgrywaja gospodarki azjatyckie, które od lat 70. XX wieku przeżywaja okres przebudzenia. Globalizacja stosunków gospodarczych wydaje się już dziś nie do zatrzymania, jedynie jej charakter ulega przekształceniom wraz z rozwojem wiedzy, technologii i postępem cywilizacyjnym.

Wobec wspomnianych dynamicznych zmian zachodzących w gospodarce globalnej funkcjonowanie systemu globalnego zarządzania staje się ogromnym wyzwaniem. Organizacje i instytucje odpowiedzialne za kształtowanie reguł i zasad współistnienia podmiotów na arenie międzynarodowej często funkcjonują w oparciu o struktury stworzone kilkadziesiąt lat temu. Przykładem jest Rada Bezpieczeństwa ONZ, w której zasiada pięciu stałych członków (USA, Rosja, Chiny, Wielka Brytania i Francja) mających prawo weta, co przeczy demokratycznym zasadom podejmowania decyzji. Podobnie jest z Międzynarodowym Funduszem Walutowym, w którym liczba głosów, jakimi dysponuja poszczególne państwa członkowskie przy dystrybucji środków, powinna odzwierciedlać ich rolę w gospodarce światowej, jednakże pomimo rosnącego znaczenia krajów rozwijajacych się siła ich głosów

${ }^{10}$ H.J. Morgenthau, K.W. Thompson, Polityka miedsy narodami. Walka o potege i pokój, tłum. R. Włoch, wydanie skrócone, Warszawa 2010, s. 296. 
pozostała taka sama od wielu lat. Zmiany można by wprowadzać pod warunkiem zaaprobowania ich przez 85\% głosów państw członkowskich. Jest to jednak trudne do osiagnięcia chociażby dlatego, że Stany Zjednoczone mające 16\% głosów sa w stanie zawetować każdą decyzję w tym zakresie ${ }^{11}$. Kolejnym przykładem jest Bank Światowy, którego prezesa teoretycznie wybieraja jego dyrektorzy, jednak w praktyce zostaje nim zawsze Amerykanin, którego kandydatura jest zgłoszona przez prezydenta Stanów Zjednoczonych. Kraj ten posiada największy udział w kapitale zakładowym, a tym samym ma największą liczbę głosów.

Dominacja Stanów Zjednoczonych uznawanych za lidera współczesnego świata jest widoczna w wielu kluczowych międzynarodowych organizacjach i instytucjach decydujących o losach współczesnego świata. Podejmowane sa jednak próby dokonywania pewnych zmian, aby proces decyzyjny był bardziej demokratyczny. Przykładem podmiotu, w którym każde państwo ma jeden głos podczas podejmowania decyzji, jest Światowa Organizacja Handlu, jednak i jej często zarzuca się niedemokratyczny charakter i promowanie interesów największych potęg gospodarczych na świecie. Ponadto w obliczu trwającego impasu w negocjacjach w ramach rundy Doha oraz gwałtownego wzrostu liczby zawieranych regionalnych porozumień handlowych (RTAs Regional Trade Agreements) znaczenie tej organizacji systematycznie słabnie.

Do osłabienia roli W'TO zdecydowanie przyczyniły się Stany Zjednoczone. Wykorzystując sposób podejmowania decyzji na zasadzie konsensusu, zablokowały w 2019 r. wybór nowych członków Organu Apelacyjnego WTO i uniemożliwiły tym samym poprawność rozstrzygania przez ten organ sporów pomiędzy członkami organizacji. Stany Zjednoczone i prezydent Donald Trump otwarcie krytykują WTO, grożąc nawet jej opuszczeniem oraz obwiniając ją w dużej mierze za coroczny ogromny deficyt handlowy w państwie. Wprowadzenie przez WTO ograniczeń i zakazów stosowania części instrumentów polityki handlowej godzi bowiem w interesy Stanów Zjednoczonych, które dodatkowo są zwolennikiem bilateralnych porozumień handlowych, ponieważ $\mathrm{w}$ nich $\mathrm{z}$ racji posiadanego statusu zawsze maja przewagę nad partnerem. Kolejnym przejawem swoistej niechęci USA wobec WTO są zapowiedzi z lutego 2020 r., dotyczące wycofania się z zawartego w jej ramach Porozumienia w sprawie zamówień rządowych (GPA - Government Procurement Agreement), o ile jego warunki nie zostana zmienione zgodnie z wymogami Stanów Zjednoczonych. Tego typu działania podejmowane przez USA na łamach WTO potwierdzaja coraz silniej zauważalny protekcjonizm amerykańskiej gospodarki promowany przez prezydenta Trumpa. Jego wyrazem już wcześniej były takie działania, jak m.in.: wycofanie się z Partnerstwa Transpacyficznego (TPP - Trans-Pacific Partnership) w 2017 r.; nałożenie w 2018 r. ceł na import stali i aluminium z Meksyku, Kanady i Unii Europejskiej oraz na część towarów importowanych z Korei Południowej i Chin; zatrzymanie rozmów

11 M. Rewizorski, Dừo hałasu o nic? Uwagi o reformie modelu funkcjonowania Międrynarodowego Funduszu Walutowego, „Przegląd Politologiczny” 2017, R. 22, nr 2, s. 23, 24. 
w sprawie Transatlantyckiego Partnerstwa w dziedzinie Handlu i Inwestycji; renegocjacja postanowień NAFTA i zastąpienie jej podpisanym przez Trumpa w styczniu 2020 r. Porozumieniem o wolnym handlu pomiędzy Stanami Zjednoczonymi, Meksykiem i Kanadą (USMCA) ${ }^{12}$; a także wycofanie się w 2019 r. z paryskiego Porozumienia w sprawie zmian klimatu (decyzja ta była zapowiadana przez prezydenta Trumpa od 2016 r., jednakże kraje członkowskie nie mogły wycofać się z umowy przez co najmniej 3 lata od dnia jej wejścia w życie).

Próby poprawy bilansu handlowego przez Stany Zjednoczone odbiły się także istotnie na i tak napiętych już relacjach z Chinami. Ograniczenie importu chińskich towarów i podniesienie ceł importowych oraz wzajemne działania odwetowe doprowadziły do eskalacji konfliktu handlowego pomiędzy krajami. Jego skutki odczuły obie gospodarki, co nie przyniosło Trumpowi nowych zwolenników w perspektywie zbliżających się wyborów. W efekcie wielomiesięcznych rozmów w styczniu 2020 r. prezydent USA podpisał pierwszą część Porozumienia handlowego z Chinami, które zakłada przede wszystkim zwiększenie przez Chiny importu towarów ze Stanów Zjednoczonych oraz ograniczenie zapowiadanych przez USA działań odwetowych ${ }^{13}$.

Zdaniem wielu polityków, ekonomistów i obserwatorów stosunków międzynarodowych podejmowane w ostatnich latach przez Donalda Trumpa działania przełożyły się na osłabienie pozycji Stanów Zjednoczonych jako najpotężniejszego globalnego mocarstwa, a jego prezydenta jako lidera wolnego świata. Coraz śmielej padają zdania, że to Chiny zajmą niedługo miejsce USA, a przewodniczący Xi Jinping coraz częściej zgłasza swoją gotowość do przejęcia roli przywódcy nowego globalnego ładu.

\section{Inicjatywa Pasa i Szlaku a global governance}

Inicjatywa Pasa i Szlaku (BRI) przedstawiona w 2013 r. przez przewodniczącego Chińskiej Republiki Ludowej Xi Jinpinga jest próbą utworzenia platformy międzynarodowej współpracy opartej na rozwoju więzi przede wszystkim ekonomicznych, ale także politycznych, społecznych, kulturowych i instytucjonalnych między jej uczestnikami.

12 Zdaniem prezydenta Trumpa porozumienie NAFTA było najgorszą umową handlowa zawartą przez Stany Zjednoczone w historii, a renegocjacje warunków współpracy z Kanadą i Meksykiem były jedną z jego najważniejszych obietnic wyborczych. A. Swanson, J. Tankersley, Trump Just Signed the U.S.M.C.A. Here's What's in the New NAFTA, "The New York Times”, 29.01.2020, https://www.nytimes.com/2020/01/29/business/economy/usmca-deal.html (dostęp: 6.03.2020).

13 US A - Chiny. Co zakłada piernsza cæeśćcporozumienia handlowego?, „Forbes”, 15.01.2020, https:// www.forbes.pl/gospodarka/porozumienie-handlowe-usa-chiny-zalozenia-pierwszej-czescipodpisanej-przez-donalda/tccgvlv (dostęp: 6.03.2020). 
Często jest nazywana również ideą Nowego Jedwabnego Szlaku. Zakłada rozwój obecnych i nawiązanie przez Chiny nowych relacji handlowych. Ponieważ opiera się na rozbudowie licznych szlaków lądowych (Silk Road Economic Belt) oraz morskich (Maritime Silk Road) łączących w szczególności Chiny z Europa, można spotkać się ze stwierdzeniem, że celem BRI jest reaktywacja starożytnego Jedwabnego Szlaku. W rzeczywistości skala podejmowanych działań oraz rosnących współzależności pomiędzy gospodarką chińską a krajami włączonymi do BRI uprawnia do stwierdzenia, że inicjatywa ta jest próbą stworzenia nowego międzynarodowego ładu gospodarczego i politycznego, dzięki której Chiny odzyskają miano światowego przywódcy - potęgi gospodarczej, którą były niegdyś. Zaangażowane w realizację tej idei są bowiem nie tylko Chiny i kraje europejskie. Sieć połączeń obejmuje gospodarki Azji Wschodniej, Południowo-Wschodniej, Azji Centralnej, Afryki, a nawet Ameryki Łacińskiej. Zgodnie z danymi Międzynarodowego Instytutu Zielonych Finansów Centralnego Uniwersytetu Finansów i Ekonomii (International Institute of Green Finance CUFE) w Pekinie do stycznia 2020 r. Porozumienie o współpracy w ramach BRI z Chinami podpisało 137 krajów, z których: 23 pochodziło z regionu Azji Wschodniej i Pacyfiku, 34 z Europy i Azji Centralnej (w tym 18 krajów należących do Unii Europejskiej, również Polska), 18 z Ameryki Łacińskiej i Karaibów, 20 z regionu Bliskiego Wschodu i Afryki Północnej, 7 z Afryki Południowej oraz 35 z Afryki Subsaharyjskiej ${ }^{14}$.

Przedstawione dane potwierdzają duże zainteresowanie zaproponowanym przez Chiny rozwiązaniem intensyfikacji międzynarodowej współpracy. Popularność tej idei wynika m.in. z tego, że kooperacja w ramach BRI ma opierać się na formule win-win, dzięki której zyskają wszyscy jej uczestnicy, co przewodniczący ChRL niejednokrotnie podkreślał w różnych wystapieniach ${ }^{15}$. Należy jednak zauważyć, że na największe korzyści liczą same Chiny. Od końca pierwszej dekady XXI wieku borykały się z rokrocznym spadkiem dynamiki wzrostu gospodarczego, zaś w realizacji koncepcji Pasa i Szlaku upatrują szansę na poprawę osiąganych wyników i utrzymanie wysokiego poziomu eksportu (rys. 1).

Potwierdzeniem ogromnej skali projektu są już realizowane i planowane do roku 2049 inwestycje. Zgodnie z danymi publikowanymi przez American Enterprise Institute oraz The Heritage Foundation w raporcie: China Global Investment Tracker w latach 2013-2019 Chiny podjęły się realizacji (lub współrealizacji) aż 1355 inwestycji oraz kontraktów budowlanych w krajach BRI o łaccznej wartości ponad 730 mld USD (dane dotyczą jedynie przedsięwzięć o wartości jednostkowej powyżej 100 mln USD; rys. 2). Tymczasem w kolejnej dekadzie projekty w ramach BRI moga pochłonąć nawet do kilku bilionów dolarów.

14 Institute of Green Finance, https://green-bri.org/countries-of-the-belt-and-road-initiative-bri\# (dostęp: 7.03.2020).

15 Vision and Actions on Jointly Building Silk. Road Economic Belt and 21st-Century Maritime Silk Road, 28.03.2015, http://en.ndrc.gov.cn/newsrelease/201503/t20150330_669367.html (dostęp: 7.03.2020). 


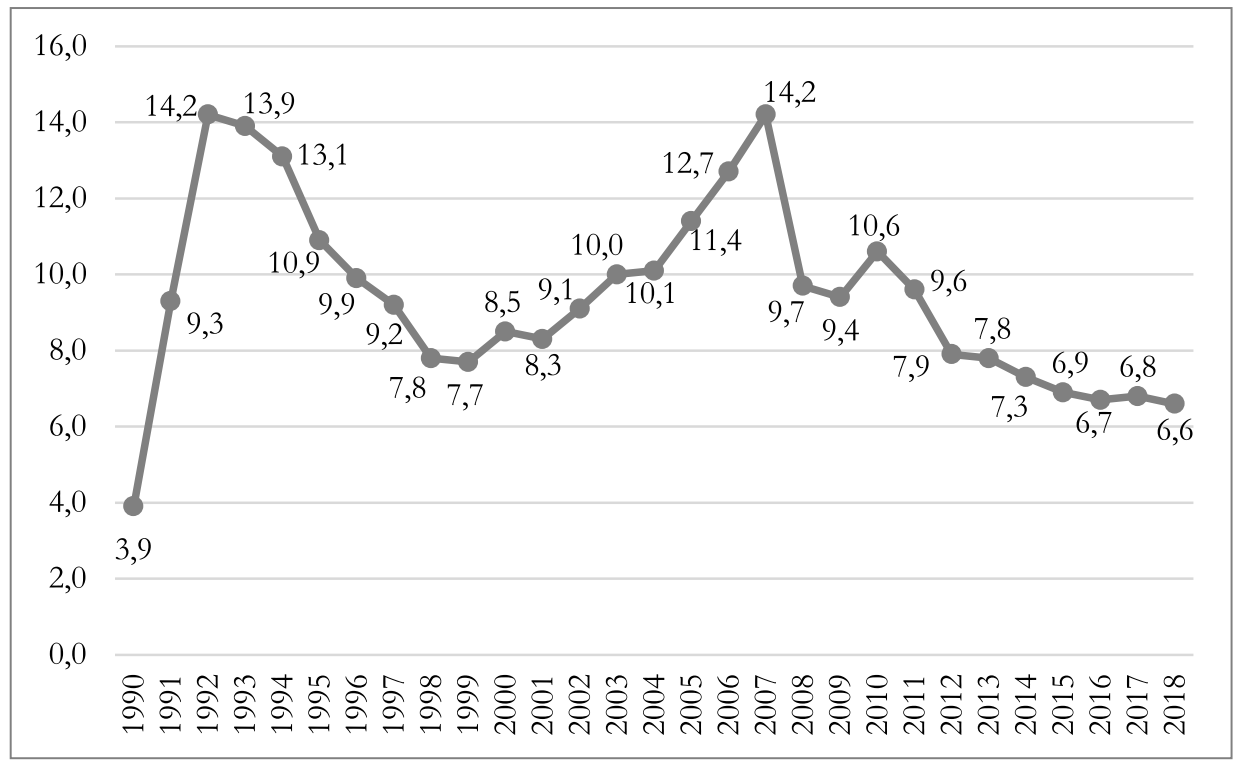

Rys. 1. Dynamika wzrostu PKB Chin (\%) w latach 1990-2018

Źródło: Opracowanie własne na podstawie: World Bank Database, https://data.worldbank.org/indicator/NY.GDP.MKTP.KD.ZG?end=2018\&locations $=C N \& s t a r t=1990 \& v i e w=$ chart (dostęp: 8.03.2020).

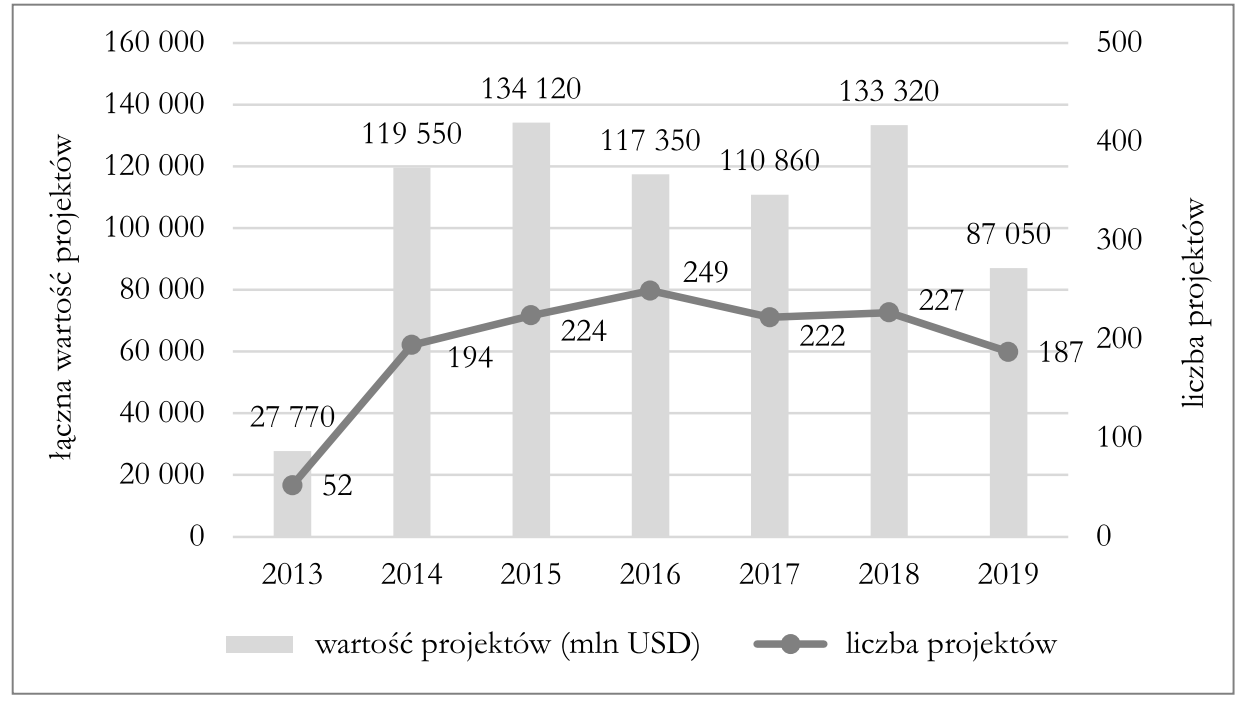

Rys. 2. Chińskie projekty w ramach BRI w latach 2013-2019

Źródło: Opracowanie własne na podstawie: China Global Investment Tracker, https://www.aei.org/ china-global-investment-tracker/ (dostęp: 8.03.2020). 
Jeśli przeanalizować chińskie inwestycje w latach 2013-2019 pod kątem ich struktury branżowej, to widać, że wyraźnie przoduja projekty realizowane w sektorze energetycznym $(39 \%)$ oraz transportowym $(26 \%)$. Kolejne miejsca przypadaja na sektory: nieruchomości $(10 \%)$ i wydobycia metali (7\%). Z kolei ich struktura geograficzna kształtowała się w badanym okresie następująco: Azja Wschodnia (25,74\%), Afryka Subsaharyjska (21,68\%), Azja Zachodnia (21,37\%), Bliski Wschód i Afryka Północna (14,53\%), Europa (9,18\%), Ameryka Południowa (6,48\%), Ameryka Północna $(1,02 \%)^{16}$.

Wspomniany wcześniej protekcjonizm realizowany przez Stany Zjednoczone w ostatnich latach, świadczący o ich zwrocie w stronę ekonomicznego nacjonalizmu wydaje się szansą dla przewodniczącego ChRL Xi Jinpinga na zwiększenie strefy wpływów na świecie, a realizowana z dużym rozmachem Inicjatywa Pasa i Szlaku (o ile przyniesie oczekiwane skutki) może mu pozyskać znaczną grupę zwolenników. Dlatego też idea Nowego Jedwabnego Szlaku nazywana jest największą strategia geopolityczną XXI wieku, która doprowadzi do powstania wielobiegunowego świata, mającego zastąpić obecną jednobiegunową formę, przypisującą Stanom Zjednoczonym kluczową rolę. Zdaniem części ekonomistów oprócz Chin ład światowy uzupełnia wspólnoty religijne: muzułmańska i chrześcijańska ${ }^{17}$. Czy Inicjatywa Nowego Jedwabnego Szlaku stanie się jednak impulsem do reformy obecnego systemu globalnego zarządzania?

Wydaje się oczywiste, że ekonomiczna ekspansja Chińskiej Republiki Ludowej realizowana za sprawą Inicjatywy Pasa i Szlaku przyniesie zmiany nie tylko w gospodarce globalnej, ale także przyczyni się do światowej ekspansji chińskiej cywilizacji (podobnie jak to było z amerykanizacją, makdonaldyzacja życia społecznego) oraz zmian w globalnej polityce i systemie globalnego zarządzania. Chiny nie ukrywaja swoich ambicji, by stać się światowym mocarstwem oraz by w oparciu o „chiński sposób” dokonać istotnych zmian w systemie globalnego zarządzania. W 2018 r. wymieniano to nawet wśród głównych celów chińskiej dyplomacji. Ów „chiński sposób” opiera się z jednej strony na tzw. wspólnocie losów, z drugiej zaś na szerszym uznawaniu wartości moralnych i sprawiedliwości we wzajemnej współpracy. Chiny są zwolennikiem pokojowej kooperacji wpisującej się w konfucjański paradygmat wszechobecnej harmonii, w przeciwieństwie do współczesnej polityki światowej, w której cywilizacje europejska i amerykańska kontynuują sposób prowadzenia polityki opartej na dominacji militarnej ${ }^{18}$.

Swoistym paradoksem stało się jednak, że to przewodniczący ChRL (kraju, którego system polityczny wykazuje tendencje autorytarne, a system gospodarczy nie

${ }^{16}$ China Global Investment Tracker, https://www.aei.org/china-global-investment-tracker/ (dostęp: 8.03.2020).

17 J. Sulmicki, Chiny swriatonym hegemonem w nowym tadzie globalnym, „Kwartalnik Naukowy Uczelni Vistula" 2018, nr 4(58), s. 122.

18 Ibidem, s. 110-124. 
do końca można traktować jako w pełni rynkowy) nawoływał w 2017 r. na Forum Ekonomicznym w Davos do kontynuowania idei wolnego handlu w skali międzynarodowej, gdy tymczasem prezydent USA (kraju, który zawsze był traktowany jako wzór demokratycznych wartości, praw obywatelskich i gospodarki wolnorynkowej) wprowadza protekcjonizm gospodarczy pod hasłami: America First oraz Make America Great Again. W obliczu zachodzacych zmian Xi Jinping podczas wizyty w Genewie w styczniu 2017 r. przedstawił swoją wizję budowy wspomnianej wspólnoty losów (community of common destiny for mankind), dzięki której będzie możliwe osiągnięcie i dzielenie rozwoju korzystnego dla wszystkich stron. Niedługo później postulat ten został uwzględniony w rezolucji ONZ.

Oprócz wezwania do podjęcia międzynarodowych wysiłków na rzecz kontynuowania dialogu politycznego dotyczącego wspólnego bezpieczeństwa i dobrobytu, a także wspólnego dbania o społeczny i ekologiczny rozwój, Xi Jinping potwierdził także zaangażowanie Chin w globalny rozwój, czego dowodem sa ciagłe postępy Inicjatywy Pasa i Szlaku ${ }^{19}$. Za pomoca głoszonych haseł „wspólnoty losów" oraz kooperacji na zasadach win-win Chiny chcą chronić globalny pokój i stopniowo reformować światowy porządek. Wyrażają tym samym swój sprzeciw wobec tego, aby mocarstwa światowe miały prawo do narzucania innym krajom swoich rozwiązań oraz decydowania o losach wszystkich. Zdaniem przewodniczącego ChRL w czasach zachodniego przywództwa mocarstwa jedynie rywalizują o władzę i dbają o swoje interesy. Jednakże należy zgodzić się ze zdaniem Justyny Szczudlik - eksperta Polskiego Instytutu Spraw Międzynarodowych - że choć Chiny chca zreformować obecny system global governance i maja ku temu ambicje, to póki co nie jest to jeszcze możliwe. Przemawia za tym kilka argumentów, m.in. ${ }^{20}$ :

- brak wystarczającej liczby sojuszników politycznych, którzy na ten moment otwarcie poparliby ich w tej reformie,

- fakt, że Chiny jak na razie zyskują na obecnym ładzie światowym,

- opór Chin w reformie WTO, która mogłaby doprowadzić do wprowadzenia bardziej restrykcyjnych przepisów, np. w stosunku do stosowania rządowych subsydiów,

- uznawanie się za państwo rozwijające, czym usprawiedliwiaja podejmowane przez siebie działania protekcjonistyczne,

- problemy wewnętrzne o charakterze gospodarczym i społecznym.

Biorąc pod uwage powyższe, Inicjatywę Pasa i Szlaku należy dzisiaj traktować jako ideę, która ma przysporzyć Chinom zwolenników i sprzymierzeńców.

\footnotetext{
19 Zhang Chun, The Belt and Road Initiative and Global Governance in Transition, „China Quarterly of International Strategic Studies" 2017, vol. 3, no. 2, s. 175-191.

20 J. Szczudlik, Chiny a (nowy?) swiatowy ład, „Teologia Polityczna”, 3.02.2020, https://teologiapolityczna.pl/justyna-szczudlik-chiny-a-nowy-swiatowy-lad (dostęp: 8.03.2020).
} 
W przyszłości będą ich bowiem potrzebować, aby zmienić zasady globalnego zarządzania. Jeśli spojrzeć na obecny układ sił w gospodarce globalnej i rosnącą rolę geopolityczną Chin, to wydaja się one dziś jedynym podmiotem, który mógłby zreformować system global governance, jednak proces ten jest długofalowy i zdecydowanie jest na to jeszcze zbyt wcześnie.

\section{Podsumowanie}

Inicjatywa Pasa i Szlaku to przedsięwzięcie, które zdecydowanie znacząco wpłynie w najbliższych dekadach na gospodarcze losy świata. Jego realizacja z pewnością niesie za sobą wiele szans dla wszystkich podmiotów w nim uczestniczących, w szczególności Chin, ale nie należy zapominać o czyhających zagrożeniach. Finalizacja tak wielu projektów jednocześnie może spowodować problemy z ich koordynacją. Ponadto wymaga ogromnych nakładów kapitału, często nie tylko po stronie chińskiej, ale także kraju, w którym inwestycje są realizowane. Ich ewentualna strata spowodowałaby wielkie problemy gospodarcze zarówno dla kraju przyjmującego, jak i dla Chin, a także osłabienie chińskiej reputacji na arenie międzynarodowej. W ciagu 6 lat rozwoju idei Pasa i Szlaku pojawiły się problemy z realizacją niektórych projektów, co wymagało od władz chińskich wielu zabiegów, aby utrzymać w partnerach wiarę w powodzenie całej inicjatywy. Rosnąca liczba krajów przystępujących do Nowego Jedwabnego Szlaku świadczy jednak o tym, że płynące z niej dla nich korzyści przewyższają koszty. Umacnia to też pozycję Chin i przysparza im nowych sojuszników.

Działania podejmowane w ramach BRI mają istotny wpływ na system globalnego zarządzania, którego obecna formuła wymaga reformy. Wydaje się jednak, że rosnąca pozycja geopolityczna Chin jest mimo wszystko na ten moment jeszcze zbyt słaba, aby można było dokonać istotnych zmian w tym zakresie. $Z$ racji złożoności zagadnienia zmiany te muszą być bowiem dobrze przemyślane i powszechnie zaakceptowane. Ponadto choć wiek XXI nazywany jest stuleciem Azji, a Stany Zjednoczone, które dominowały w gospodarce światowej w wieku XX, w ostatnich latach prezentują postawy antyglobalizacyjne i wydawać by się mogło, że ich pozycja światowego mocarstwa słabnie, to na pewno nie powiedziały jeszcze ostatniego słowa w zakresie geopolitycznej dominacji. 


\section{SUMMARY}

\section{THE ROLE OF BELT AND ROAD INITIATIVE IN THE AREA OF THE GLOBAL GOVERNANCE SYSTEM}

The Belt and Road Initiative is an idea that raises strong emotions on the international arena since its announcement in 2013. The scale of this undertaking and the objectives that guide its implementation prove that it can have a significant impact on the balance of power in today's international relations. The main goal of this article is to try to answer the question whether the New Silk Road is China's way to reform the global governance system. If so, to what extent? In the preparation of the article, a method of describing economic reality was used and conclusions were drawn regarding the future of global governance. The main result of the analysis is the thesis that, looking at the current balance of power in the global economy and the growing geopolitical role of China, it seems to be the only entity that could change the current shape of global governance system, but it is a long-term process and it is definitely too early today. 